\title{
8
}

\section{The Imperial Banquet of 13 August 1816 and Progress to Tongzhou}

Amherst's arrival at Tianjin marked the start of official negotiations with the Chinese Government on the occasion of an imperial banquet that Macartney had managed to avoid at the time of his embassy. ${ }^{1}$ Historians have ignored the critical role and significance of the banquet that served as a site of generic diplomatic conflict and a carefully planned diplomatic ambush for the British from which the embassy never fully regained its forward momentum. ${ }^{2}$ Chinese tactics at the time confirmed British views that they were dealing with a devious and inflexible 'Tartar court' that was determined to ensure that access to the emperor conformed to the protocols of the tribute system. These assessments were reinforced for the British as the embassy proceeded to Tongzhou, situated 12 miles from the emperor's Summer Palace of Yuanmingyuan.

1 Macartney was invited to a banquet at Dagu on 5 August but pleaded illness. He wrote, 'The Mandarins, Wang and Chou ... now came to visit us, and pressed us much to accept their invitation to a banquet ... which had been prepared for us, but being a good deal fatigued I declined it' (CranmerByng, 1962, p. 73). Serious discussion of the ceremony to be performed before the Qianlong emperor did not take place until 8 September at Jehol (pp. 118-119). In contrast, Amherst was confronted about the kowtow within three days of arriving in China. Barrow commented later in the Quarterly Review that 'Lord Macartney ... was more fortunate than Lord Amherst in escaping the yellow screen and the five clawed dragon of Tien-sing, where all the misfortunes of the latter originated' (1817, p. 479).

2 For example, Eastberg (2009) made no specific reference to the banquet while Gao, in his article 'Inner kowtow controversy' (2016), devoted only a paragraph to it but correctly concluded that Amherst 'paid some reverential bows without indicating he would perform kowtow before the emperor himself' (p. 601). 

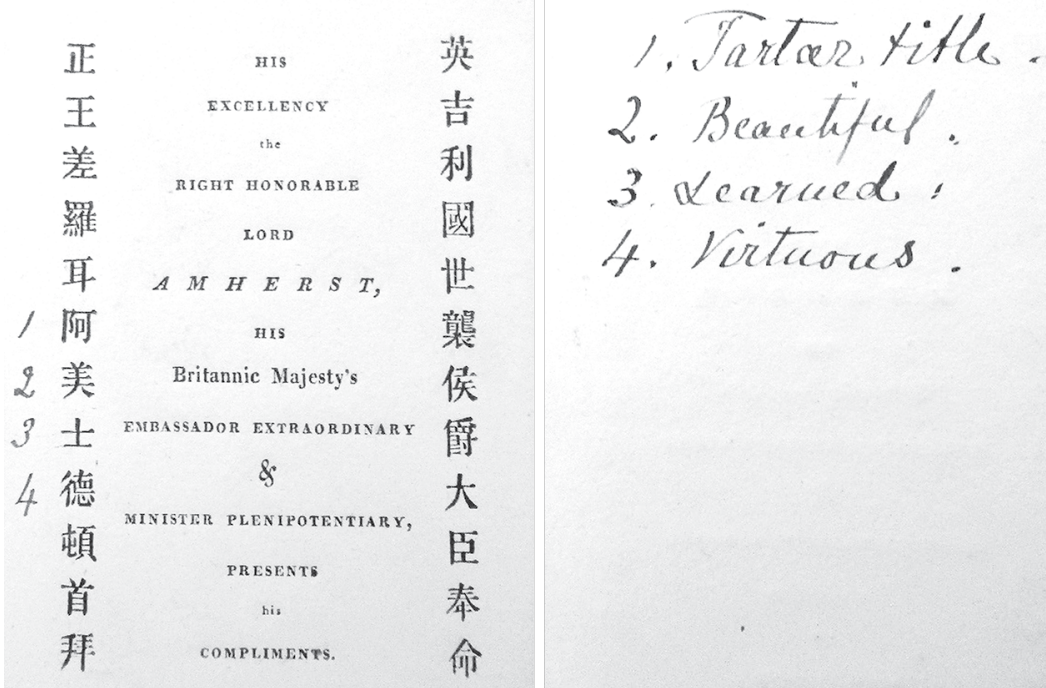

Figure 6: Amherst's official visiting card (front and back views) with an explanation of the Chinese rendering of his name.

Source: British Library.

\section{August 1816: The Imperial Banquet}

The imperial banquet hosted by the legates Guanghui and Sulenge at Tianjin on 13 August 1816, held only three days after the embassy disembarked at Dagu, represented the first of only two formal receptions granted to the Amherst Embassy in China and was the only one held in northern China. ${ }^{3}$ Amherst and Staunton recognised that it was no ordinary civil reception; rather, it was a test on their readiness to comply with the kowtow ceremony (Staunton, 1824, p. 44; Amherst to Canning, 12 February 1817, in BL IOR G/12/197 (Reel 2) F 218). The day was also very hot, with Hayne (n.d., vol. 2, p. 20) recording an afternoon temperature of $93^{\circ} \mathrm{F}\left(33.8^{\circ} \mathrm{C}\right)$. For the British, the occasion presented an opportunity to make a suitable display befitting the embassy's first public appearance in China. Leading the parade on horseback were lieutenants Cooke and Somerset, in full uniform and bearing the Colours of England. The marine guard marching two by two followed, accompanied by the band. Amherst, the commissioners

3 The second reception was at Canton on 7 January 1817 after Amherst's return from Peking. 
and Jeffrey were borne by Chinese palanquins. Amherst wore his 'peeral' robes over his Windsor uniform; Staunton was in the gown and cap of the Fellow Commoner of Cambridge; and Ellis wore his Windsor uniform without a sword. The rest of the suite were resplendent in the blue and scarlet embroidered uniform of the embassy, with gold lace coats, round hats, pantaloons and boots (Hayne, n.d., vol. 2, p. 20). Chinese soldiers cleared a path through the immense though silent crowd that had gathered as the procession made its way through the narrow streets of Tianjin.

The reception took place in a makeshift building of bamboo and plaited matting purposely built for the banquet. This venue represented a stark contrast to the grand stone buildings of Europe normally associated with diplomatic receptions. A hushed crowd at the entrance watched as the British alighted and entered an outer court lined with Chinese bowmen. Several mandarins dressed in their ceremonial robes stepped forward to meet the British and conducted them to a large hall. ${ }^{4}$ Staunton's earlier suspicions were confirmed. Amherst wrote:

The first thing that caught my eye on entering the room was a table covered with yellow silk evidently intended as a symbol of the Imperial Presence. Having read in a journal of the Russian Embassy in 1805 that the Russian ambassador soon after passing the frontier had been invited to a banquet, and then had been required to perform the Ko-tow ... I concluded it was intended to put me to the same test, and having made up my mind, whatever ceremony I might afterwards submit to in the presence of the Emperor himself, to refuse prostration to any mere representation of the Imperial Person, I anticipated a similar fate to that of the Russian Embassy and was prepared to find, at Tien-sing, a final termination to our progress. (Amherst to Canning, 12 February 1817, in BL IOR G/12/197 (Reel 2) F 219)

Amherst, Staunton, Ellis, Morrison and Jeffrey were conducted into an inner apartment where the two legates Sulenge and Guanghui and four other mandarins were waiting. The Chinese sat on the left side of the room and gave the British seats on the less honourable right-hand side. The British, Guanghui emphasised, were being honoured by an imperial banquet expressly commanded and given by the emperor and it was to be assumed that the emperor himself was present. Accordingly, the kowtow was to be performed in return for the emperor's benevolence.

4 State banquets and the food served were managed by the Court of Banqueting, an agency of the Board of Rites (see Rawski, 1998, p. 43). 
Amherst replied that his orders came directly from the King of England and he was unable to comply with the Chinese request to kowtow. Rather, he intended to show the same respect to the emperor as he would to his own sovereign and would follow Macartney's precedent as commanded by the king. In the presence of the emperor he would kneel on one knee, bow his head and kiss the emperor's hand as a mark of affection. ${ }^{5}$ But on the present occasion, where the physical presence of the emperor was absent, he would perform the same ceremony paid by the Lords before the vacant throne of the British sovereign in the House of Lords, a low bow. As a conciliatory gesture to the mandarins, Amherst agreed to bow nine times in unison with the number of 'kneelings' performed by them (Morrison, 1820, p. 29).

Kissing the emperor's hand, the mandarins replied, was unacceptable and asserted, with what Jeffrey described as the 'the most obstinate perverseness', that Macartney had kowtowed, not only in the presence of the emperor but at other times as well, whenever the occasion demanded (Staunton, 1824, p. 46; Ellis, 1817, p. 92). Sulenge recalled that he remembered Macartney performing the kowtow at Canton and appealed to Staunton, who had been present on that occasion, to vouch that this was the case (Staunton, 1824, p. 47). Staunton was evasive. The embassy was so long ago, and he had been so young, that he could not remember which ceremony had been performed, but he was certain that it was not the kowtow (Staunton, 1824, p. 47). ${ }^{6} \mathrm{He}$ reaffirmed Amherst's position

5 The tradition of a ceremonial kissing of the hand in European diplomacy was an act of submission performed by the great lords of the realm (see Ruiz, 1985, p. 125).

6 Historical controversy surrounds the question of whether Macartney kowtowed before the Qianlong emperor in 1793. An entry in Staunton's boyhood diary, dated 14 September 1793, describes the British standing by the side of the road as the emperor passed where, he wrote, 'we went on one knee and bowed our heads down to the ground'; 'down to the ground' is crossed out. Later that day, at a reception before the emperor, Staunton referred to 'making the proper ceremony', assumed by some to suggest the Chinese ceremony of the kowtow. But, on 30 September, Staunton referred to performing 'the usual ceremony of Bending one knee'. Back in Canton, the mandarins made nine bows and three genuflections before a throne representing the emperor where the British, according to Staunton, 'followed their example' (Sir George Thomas Staunton, Diary 1792-1793: Journey to China, 1792-1793, London, England: Adam Matthew Microform Publications (China Trade, Politics \& Culture, 1793-1980 database). Retrieved from www.china.amdigital.co.uk). These descriptions have led some historians, including Rockhill $(1897,1905)$ and Pritchard (1943), to conclude that Macartney kowtowed. Rockhill (1905, p. 31) based his claims on a report by a Russian interpreter, Vladykin (based in Peking at the time), that claimed Macartney had performed 'the detested prostrations'. Pritchard (1943, p. 166) referred to a French savant, M. Pierre Abel-Ramusat, who, following Russian sources, also reported that Macartney had kowtowed. A more realistic assessment is made by Peyrefitte (1992, pp. 224-225) who correctly points out the physical impossibility of Macartney - 53 years of age, overweight, gout ridden and wearing tight silk trousers-kowtowing. Further, it is almost impossible for the average person to touch the ground with their head while kneeling on one knee! 
that the British would follow Macartney's precedent, recorded in his official report, which was the most authentic authority on the subject. 'However mortifying to his feelings', Amherst said, he had no choice but to decline the honour of the emperor's invitation and would forego the banquet altogether (Ellis, 1817, p. 93). This, Staunton wrote later, would 'get rid of the difficulty for the present', but, by doing so, the mandarins had argued, he would be treating the emperor's kindness with contempt (1824, p. 47).

Discussions on the subject dragged on for two hours, made especially tedious, it would seem, by the logistics of interpreting and the very hot weather. The mandarins appealed to Amherst's paternal feelings, suggesting it would be a great shame if Jeffrey was deprived of the opportunity of seeing the emperor (Ellis, 1817, p. 94). Macartney had kowtowed, the mandarins argued, and it was necessary for Amherst to practise the ceremony. Amherst 'strenuously denied' such claims and diplomatically pointed out that the obeisance Macartney paid to the Qianlong emperor should be acceptable to his son. The mandarins refused to accept Amherst's argument and pointed out, significantly, that the Jiaqing emperor had been present on the occasion of Macartney's audience with his father and would vouch that Macartney had kowtowed.

Amherst next proposed that he would prepare a letter stating his reasons for not kowtowing and would present it to the emperor at Peking, but this was not acceptable. The Qianlong emperor, Amherst was informed, was most unhappy with Macartney's European homage and had been adamant that it should not become a precedent for future occasions. 'The Emperor', Guanghui added, 'would be angry with the King of England', which so offended Morrison that he dared not translate it (Morrison, 1820, p. 30). Amherst, however, read the admission of the Qianlong emperor's disapproval as proof that the mandarins had lied in their assertions that Macartney had kowtowed. A compromise was suggested. He would bow before the altar table the same number of times as the mandarins kowtowed, thereby showing his respect to the emperor, but he would not transgress his sovereign's orders. The emperor, he was confident, would understand his position. His embassy, he pointed out, had been in China for only three days after a six-month voyage-surely the emperor would not be so unreasonable to expel the embassy. This proposal was eventually accepted 'with good grace'. It was agreed that Amherst would make nine bows before the imaginary presence of the emperor (Amherst to Canning, 12 February 1817, in BL IOR G/12/197 (Reel 2) F 227). 
The party adjourned for lunch and returned to the banquet hall. Guanghui told Amherst that he was very unhappy with his decision not to kowtow and cautioned that it would be wise for him to 'reconsider the consequences that might result' from a refusal to perform the correct ceremony (as quoted in Ellis, 1817, p. 96). Morrison (1820) quoted the legate as saying:

Return thanks in your own way, and whatever it be, we shall report it to the court ... you will give offence if you do not conform; we warn you of the consequences; do not reflect on us hereafter. (p. 30)

Morrison described Sulenge as 'screwing up his arch mouth', and saying in a serious tone, 'Do conform! Imitate us! If you do not, it will not be well!' (p. 31). Negotiation on the subject had reached a crisis point. It was clear, Staunton thought, that there was no chance for any 'reconsideration or consultation, as we had no option' (Staunton, 1824, p. 96). Jeffrey thought his father's refusal to perform the kowtow was likely to result in the embassy being 'sent back without seeing his Imperial Majesty' (Jeffrey Amherst, n.d., n.p.).

With the prospect of the ceremony taking place beside the altar, Amherst informed the others of his suite that they were to follow his example, 'by bowing in the same respectful manner we should do to our own Sovereign' (Hayne, n.d., vol. 2, p. 25).

The British were confronted with an altar table covered in a yellow silk cloth embroidered with gold dragons. A lighted censer that spewed smoke sat on top of the table. Placed behind the table was a carved screen 'of curious workmanship, representing a vine in full fruit' and made up of glass gems of different colours (Abel, 1818, p. 81). Abel (1818) noted that this represented the 'symbolic presence of His Chinese Majesty' (p. 81). Situated on the floor in front of the table were several small, red-coloured rugs, placed to accommodate the 'faithful votaries' (p. 81). Two Chinese, standing beside the table, commenced the ceremony with a 'slow chant' (Jeffrey Amherst, n.d., n.p.). The six mandarins situated themselves on the right-hand side of the table. Amherst stood on the left-hand side while Staunton, Ellis and Morrison stood behind him. Abel wrote:

At a signal given by an officer, who uttered a few words in an exalted and singing tone, the Mandarins fell on their knees, and inclining their heads, knocked them three times against the ground, and then arose. A second and a third time the signal was repeated, 
and a second and a third time they knelt and knocked their heads thrice against the earth. The Commissioners and the gentlemen of the suite bowed respectfully nine times. $(1818$, p. 83$)$

At the conclusion of the ceremony, the parties adjourned for the meal, which was described by Ellis (1817, p. 96) as 'handsome' and served in the Chinese style. Amherst, Jeffrey and the commissioners were invited to the upper part of the hall where they sat on cushions, six or eight inches from the ground before very low tables barely 12 inches high, facing the mandarins seated opposite them on the left-hand side (Morrison, 1820, p. 32; Hayne, n.d., vol. 2, p. 27). They had their own separate table where they dined alone with no opportunity to converse with their fellow diners, representing an inversion of Western dining protocol. The rest of the embassy suite sat on the ground on which a red felt cloth was placed. Sitting on the floor for the British dressed in their heavy robes was exceedingly difficult and even painful. Morrison wrote:

We were compelled by this arrangement to sit cross-legged. Some of our party, incapable of this, stretched their legs under the tables ... from the awkward posture in which we sat, it was a most uncomfortable meal. (1820, p. 32)

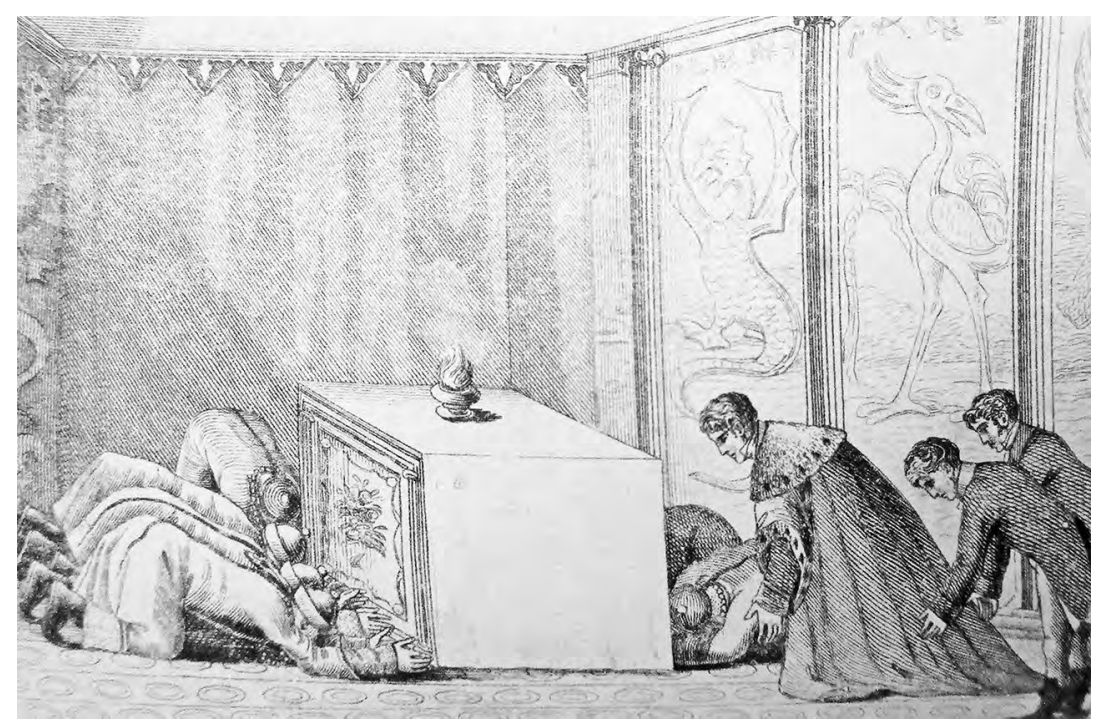

Figure 7: The frontispiece of an anonymous critique of the Amherst embassy, Sketches of China (1820), depicting Amherst kneeling before the altar table while the mandarins kowtow.

Source: British Library. 
Martin added that they were 'forced to sit ... Tartar fashion cross-legged like our English taylors' (Journal of Sir William Fanshawe Martin, 1817, p. 32, in BL ADD MSS 41346-41475). Sennett's (1994, p. 340) observation that comfort for Europeans in the late eighteenth century meant freedom of movement, even when sitting, illustrates the practical difficulties confronting the British on this occasion. The meal lasted about an hour. 'Strings of trays were brought and fitted in the square tables before us, each one for 2 persons with a dozen basons or small dishes each' (Hayne, 1820, vol. 2, p. 27). The food, according to Staunton (1824), was 'exceedingly well dressed'. He added:

Those of our party, who had no prejudice against Chinese cookery $\ldots$ and were enabled to use the chop-sticks in the absence of the knife and fork, partook of the feast very heartily. (p. 50)

Ellis did not enjoy the food, although he found the first course of preserved fruits and custard 'very palatable'. The shark fin was not to his taste and he thought the 'bird-nest soup ... too gelatinous and insipid'; it even remained bland even after the addition of 'shrimps, eggs, \&c' (Ellis, 1817, p. 102). Hayne, on the other hand, found the food 'remarkably good ... especially the birds nest and shark's fin' (Hayne, n.d., vol. 2, p. 27). Other dishes served included a soup made of mare's milk and blood, heart sinews 'and other viands used by the Chinese for their supposed aphrodisial virtues' (Abel, 1818, p. 84). Ellis and Staunton enjoyed the warm Chinese wine and the mandarins 'were very attentive in pledging the Ambassador and commissioners every time the cups were presented' (Staunton, 1824, p. 50). Martin described their Chinese hosts 'encouraging us to drink by showing us the bottom of their cups' (Journal of Sir William Fanshawe Martin, 1817, p. 32, in BL ADD MSS 41346-41475).

The guests were entertained by a Chinese orchestra and a play whose plot was indecipherable to the British, although the well-presented stage sets and colourful costumes were admired. These, Abel thought, resembled the clothes of the Chinese before the Tartar conquest (1818, p. 84). The music, consisting of a 'hubbub of noises proceeding from gongs, drums, cymbals, and everything else calculated to deafen the ears' offended British sensibilities (Davis, 1841, p. 70). Ellis was reminded of bagpipes and thought it 'might have been tolerated by Scotsmen, [but] to others [the music] was detestable. Of the same description was the singing' (1817, p. 102). The Chinese tumblers, on the other hand, were greatly admired for their strength and agility (p. 102). 
At the meal's conclusion, Amherst, Jeffrey and the commissioners were invited once again into the inner apartment to resume discussion on the kowtow ceremony. 'The test of the yellow curtain', Staunton wrote, 'had failed to produce the desired effect' $(1824$, p. 50). The legates 'now pressed for a verbal pledge' of the ceremony the English proposed to perform in the actual presence of the emperor (p. 50). Repeating that he planned to follow Macartney's precedent and bend one knee as he would before his sovereign, Amherst was requested to give a demonstration of the British ceremony before the mandarins to enable them to make an accurate report to the emperor. Amherst replied that this was not possible. An impasse was averted when:

Sir George Staunton ... happily suggested, that Lord Amherst's son should perform the proposed ceremony before his father. Chinese usage was so completely in accordance with this manifestation of respect from a son to his father, that every difficulty or objection to any previous practice by Lord Amherst was removed, and the proposition was instantly admitted. (Ellis, 1817, p. 97)

A carpet was produced and Jeffrey performed the ceremony. The mandarins, in Jeffrey's opinion, were 'still very dissatisfied, and complained that we did not shew the Emperor proper respect' (Jeffrey Amherst, n.d., n.p.). Amherst was asked to clarify if he proposed to repeat the ceremony nine times. Amherst agreed to do so but pointed out that this was more than he would perform before any European monarch. The mandarins asked if Jeffrey could repeat his earlier bow but perform it nine times. Amherst refused, telling the mandarins that he had no wish to 'trifle with a ceremony' that he considered a serious one (Amherst to Canning, 12 February 1817, in BL IOR G/12/197 (Reel 2) F 231). The mandarins insinuated that a refusal to kowtow could have serious consequences for the wellbeing of British trade at Canton. Amherst ignored such threats. Staunton had assured him earlier that a performance of the kowtow would be much more damaging to Company interests than non-compliance. Amherst's refusal to change his mind brought discussion on the ceremony to a close. The legates were handed a copy of the Prince Regent's letter to the emperor and the conference concluded. 


\section{An Analysis of the Banquet}

Scholarly reference to the Amherst Embassy has been confined to the context of the 'kowtow question', but little attention has been given to its initial reception at the banquet just described. The occasion of the banquet represented an important site where knowledge about each other was produced for both the British and Chinese and where each other's intent was weighed and gauged (Hampton, 2009, p. 4). Each side scrutinised the other through performance and both were highly sensitive to this intense scrutiny. The British arrived with a splendid display of pomp and pageantry but, on entering a Chinese space, found themselves forced to respond to Qing pressure over the kowtow. Jonathan Spence (1998, p. 43) refers to the official banquet as one of the most central and solemn moments of ritual in Chinese diplomatic intercourse. The banquet's importance for the Amherst Embassy was a critical test and served to dispel British notions that it was possible to negotiate as equals with the Qing court.

The British, it was seen, travelled to the banquet hall within the reassuring space of a formal European cortege insulated from the Chinese crowds. Abel (1818) described his efforts to scan the crowd for glimpses of women and was surprised that many of the 'well-dressed and interesting children [had] so little of the Chinese character in their faces, that they would scarcely have attracted attention in an English crowd' (p. 80). 'The men', Abel thought, were 'generally well made and frequently tall [and I] did not observe in them that uniformity of countenance which I had been led to look for in the Chinese' (p. 80). Hayne was of the same opinion:

I had here a better opportunity of contemplating innumerable faces, \& I must do them the justice to say that they were by no means an ill-looking race one with the other, nor so dark as those in the country we had passed. I think any unprejudiced person would come to the same conclusion after making allowances for the shaved head, [and] ugly dresses both of which we have been unaccustomed to see. (n.d., vol. 2, p. 22)

Hayne and Abel were reassured with the sight of physically attractive people. The sociologist Erving Goffman's insight referring to peoples' reaction to being among crowds is relevant to the British frame of mind at this time: 
By scanning one's surroundings through an image repertoire, subjecting the environment to simple categories of representation, comparing likeness to difference, a person diminishes the complexity of [alien] experience. (as quoted in Sennett, 1994, p. 366)

On arrival at their banquet destination, the British left behind the secure confines of a British space, represented by the military order of the marine guard and procession, and entered into the Chinese-controlled space of the banquet hall. The visual and olfactory markers, such as cooking smells and incense smoke, were especially confronting to the British and exacerbated preconceived cultural images and meanings of China. The visual impact of the hall's interior was commented on by Abel:

It is difficult to describe the glittering and tawdry magnificence which now suddenly opened upon us. An immense number of painted lamps, pictures, and other ornaments, in all colours of the rainbow, hung about us on every side; whilst a crowd of Mandarins, in their dresses of ceremony, rendered the animated part of the scene no less striking. $(1818$, p. 80$)$

Hayne and Abel, as well as others in the British party, were free to wander around the hall and courtyard while Amherst and the commissioners were engaged in negotiations in the conference room. British attempts were made to come to terms with Chinese culture where little of worth was seen apart from some beautiful painted lanterns and a picturesque display of presents for the embassy consisting of rolls of coloured silks 'prettily arranged in trays' on a table (Hayne, n.d., vol. 2, p. 23). The low square dining tables neatly arranged for the forthcoming meal caught Hayne's attention, while Abel (1818) described the 'pots of flowers and dwarf trees ... distributed over the room, [which] were often mingled with pieces of limestone' (p. 81). Appearances for the British were important, especially for classifying Chinese dignitaries. The historian James Epstein (1989, p. 77) has written of the importance for the British of 'flags and banners, hats and caps, ribbons and medals' during the early nineteenth century for defining state and civil power brokers. Accordingly, members of the embassy sought clues to the rank of the various mandarins by a close scrutiny of their dress. Hayne (n.d., vol. 2, p. 24) referred to badges of rank consisting of 'a tiger or Dragon for the orders of the Military and a bird for that of the civil'. Abel (1818, p. 82) also described the mandarins' finely embroidered silk petticoats 'beautifully interwoven with gold and silk, in the forms of dragons and flowers. Their boots were of satin, and 
served them for pockets'. The mandarins' hats, described as 'small and conical, covered with long red hair, and surmounted with a globe, whose colour indicated their rank' (p. 82), were of specific interest.

The different coloured hat buttons worn by the mandarins were similarly important signifiers for British recognition of rank and status of the officials they encountered, and reference was made often to the 'Red Book' that explained the colours. ${ }^{7}$ While Hayne was correct in his assertion that dragons and tigers indicated military men, he was not sufficiently educated on Chinese culture to recognise their symbolic meaning or gradations of rank (Forge, 1973, p. xiv). ${ }^{8}$ Patricia Bjaaland Welch's (2008) work on symbolic meanings in Chinese art explains that high-ranking officials of 'one to three were allowed the use of the five-clawed long dragon, while the lower ranks (four down) were only allowed the use of the four-clawed măng dragon. These dragons are virtually identical in terms of majesty and composition, the main difference being the number of claws' (p. 125). Similarly, the tiger represented 'strength, power, and courage, and, in particular, military prowess. The tiger is therefore regarded as a protector and guardian' (p. 145). While the British made a connection with the presence of dragons at the banquet with the emperor, the symbolism found on the mandarins' robes was read only in British terms as attractive and effeminate pieces of embroidery. Also noted were the girdles worn around the waists of the military mandarins from which hung 'fans, pipes, and chop-sticks' (Abel, 1818, p. 82). The contrast with the bearing of the British officers, which the British regarded as manly and military, marked a clear distinction with their Chinese counterparts on show at the banquet.

The banquet's political function, namely, to secure British compliance with the ritual performance of the kowtow, was recognised immediately by Amherst and Staunton. As explained previously, Amherst's public performance of the kowtow would have affirmed the demotion of the British sovereign to the status of a tributary vassal of the Chinese emperor. Sulenge admitted this fact in his memorial to the Imperial Government

$7 \quad$ The 'Pekin Red Book' was referred to by the British for information on Chinese ranks and family background. Ellis noted their research on Guanghui: 'On reference to the Pekin Red Book, it was found that the Chin-chae [Guanghui] is connected with the imperial family; his rank as a Mandarin is low' (1817, p. 69).

8 Forge, an anthropologist, writes in the context of art appreciation: 'Most anthropologists would suggest that it is impossible for a member of culture A to know with any meaning of a work produced in culture B unless he has had considerable experience of that culture' (1973, p. xiv). 
following the banquet. He stated he had informed Morrison, 'if the envoy knew the true meaning of reverence, he should follow us in performing the same ritual; it was only then, we said, that he could properly be regarded as having assumed an inferior status' ('Su Leng-eh and KuangHui: The Kowtow Controversy', a memorial submitted to the Imperial Government on 13 August 1816 in Li, 1969, pp. 46-47).

Amherst was ill at ease on entering the banquet hall. He had moved from a secure British space into one where his personal status as a British ambassador was in danger of being undermined as he was pressured to undergo a rite of incorporation into the Chinese politico-cultural realm (Gluckman, 1966, p. 3). The sight of the altar table draped in yellow silk alerted Amherst immediately to Golovkin's expulsion in 1806 and he braced himself for difficult negotiations with the mandarins. The censer spewing smoke on the altar table served further to remind the Protestant British of the abomination of Catholic and pagan practice. 'Kneeling' also evoked in them images of Islam or cowardice (Rawski, 1998, p. 22). ${ }^{9}$ Kneeling thus symbolised subjugation and touching the ground with one's head held connotations of uncleanliness and insult equating human behaviour with that of savage barbarians (Hevia, 1995, p. 234).$^{10}$ Sennett (1994, p. 82) has pointed out that some forms of ritual function to give bodily performance precedence over the spoken word. Diplomacy for the British was not established by the oppression of the prostrate body, but on a belief in equality based on the strength of negotiation and rational argument where participants were held responsible for their spoken words, which were recorded and documented.

Regardless of bodily positions and connotations of pagan ritual, the fundamental question concerning the performance of the kowtow, from the British point of view, was the fact that it was not reciprocal and signified subjugation of the British monarch to the Chinese emperor. This had been shown during the Macartney Embassy when the suggestion that a Chinese minister of equal rank to Macartney kowtow before a portrait of George III was refused. The kowtow, the British asserted:

9 Rawski (1998) referred to 'the ritual of submission before the emperor [being] inspired by Muslim pilgrimage traditions and thus bore religious connotations' (p. 22). It will be seen that Captain Maxwell, at the time of firing at the Bocca Tigris forts, commented on the cowardly Chinese falling on their knees in a stage of fright 'like Persians at sunrise' (Hall, 1840/1865, p. 71).

10 Hevia (2009) also quoted Stallybrass and White who argued that the kowtow represented the 'the feminization of servitude in the figure of the kneeling chambermaid' (p. 222). 
If ... not reciprocally performed ... express[ed] in the strongest manner, the submission and homage of one person or state to another and [it is] in this light the Tartar Family now on the throne of China considers the ceremony call'd San-Kwei-KewKow - thrice kneeling and nine times beating the head against the ground. (Anonymous, Handwritten background notes on the Amherst Embassy, n.p., in PRO FO 97/95)

The Amherst Embassy's fate was sealed at this early time. The legates next made a fundamental mistake in permitting the embassy to proceed towards Tongzhou before receiving official approval from the Jiaqing emperor, and before receiving confirmation of Amherst's intentions on the performance of the kowtow in the physical presence of the emperor. Amherst had kept his options open, which ensured that future diplomatic discussion would focus only on this question until a mutual agreement was reached. British objectives for the embassy were now destined to be neglected and overlooked, although they still believed that an audience before the emperor would open the door for negotiation. The banquet of 13 August had resulted in setting the diplomatic agenda where the Amherst Embassy from now on found itself on the back foot in its dealings with Qing officialdom.

\section{Aftermath of the Banquet}

Amherst, nonetheless, was very pleased with the outcome of the conference at the banquet. He had escaped Golovkin's fate and had not been expelled from China for refusing to kowtow. Importantly, he was to proceed to Peking, 'conceiving that every day of progress toward the Capital added some probability of our ultimate reception' (Amherst to Canning, 12 February 1817, in BL IOR G/12/197 (Reel 2) F 219). His reception had been civil and 'there was no mixture of rudeness or acrimony or any indication of ill-will, such as Lord Macartney had reason to complain' (Amherst to Canning, 12 February 1817, in BL IOR G/12/197 (Reel 2) F 232). Ellis (1817) recalled the fate of the Dutch embassy of 1795 where compliance with the kowtow ceremony had resulted only in the most degrading of circumstances, whereas Amherst had 'sufficiently establish [ed] the expediency of resistance' (p. 99). Hayne was impressed with Amherst's efforts to brief the rest of the embassy: 
[Of] everything that might interest them, \& even to gratify any reasonable curiosity or something to this effect which of course gave universal satisfaction $\&$ raised him still higher in the estimation of everyone. The contest was severe indeed on the disputed point, which made us glory more in our victory. (n.d., vol. 2, p. 31)

Hayne's assessment of Chinese actions reflected wider British opinion where lying and low cunning was:

characteristic of the Nation, who from beginning to end think no more of a lie than we do of eating our breakfast, which of course has done away with every thing like mutual confidence. (p. 32)

Ellis read Sulenge's assertion that Macartney had kowtowed as a deliberate attempt by the mandarins to trap Staunton into contradicting himself. To have done so, Ellis added, would have had the effect of attributing British resistance to the ceremony to his suggestions, thus undermining Amherst (Hayne, n.d., vol. 2, p. 32). The legates' acceptance of a copy of the Prince Regent's letter to the emperor signified that the embassy was still on track to proceed to Peking. But there was no guarantee that the emperor would accept the proposed British ceremony of respect.

The embassy travelled 19 miles up-river towards Tongzhou the following day and the British were astonished by the large number of junks loaded with grain destined for the Peking granaries (Ellis, 1817, p. 105). Sulenge and Guanghui informed Amherst during an evening visit that the emperor was unlikely to agree to his terms over the performance of the kowtow. Sulenge's appointment to the embassy, it was pointed out, was an unprecedented honour and indicated the emperor's high regard for Amherst because his rank was superior to any official appointed to the Macartney Embassy. Amherst, in reply, stressed that the nine bows he proposed to perform before the Jiaqing emperor represented a greater honour than the single bow traditionally paid by a British ambassador to the Russian sovereign. This gave the mandarins the opportunity to inform Amherst that the Russian embassy was expelled from China without an audience over the very question of the kowtow. Morrison wrote:

Old Soo threw out, in a rather gruff tone, that the Russians had been rejected for their non-compliance, and their commerce interrupted; and hinted that it would be the same with us. (1820, p. 35)

Guanghui added that as there was only one Sun in the universe so there was only one Sovereign in the world; this Sovereign was the Emperor of China to which all other sovereigns owed homage and submission (p. 35). 
While this statement resulted in an 'excited murmur' among the Chinese present, the British thought this proposition was 'too ridiculous to be seriously opposed' (p. 35). Guanghui and Sulenge remained steadfast and informed the British that 'they did not think there was more of a chance in ten thousand' that the emperor would receive the embassy on the terms currently proposed (Amherst to Canning, 12 February 1817, in BL IOR G/12/197 (Reel 2) F 235). The copy of the Prince Regent's letter was returned as his address to the emperor headed 'Sir, My Brother' was inappropriate and had to be changed (Staunton, 1824, p. 53). The British agreed to delete the term.

The legates next requested to see the box containing the Prince Regent's letter. The gold box, valued at $£ 1,500$ (equivalent to approximately $£ 150,000$ in today's values) and described as 'a magnificent thing of its kind' failed to attract attention whereas the appearance of the little gold silk purse given to Staunton by the Qianlong emperor evoked 'extreme veneration' and interest (Davis, 1841, p. 86).

Ellis (1817) wrote on the conclusion of the meeting that he was becoming increasingly concerned that the true objectives of the embassy were being ignored. The emphasis on ceremony and the kowtow indicated that the chances of negotiations on these were highly unlikely.

\section{August 1816}

The boats proceeded up-river towards Tongzhou for the second day. The question of the kowtow was raised again when Chang-wei and Yin visited Amherst on his barge during a stopover. Macartney, they admitted, had bowed before the Qianlong emperor on his first audience, but thereafter had kowtowed during the second audience at the time of the celebrations of the emperor's birthday. Amherst dismissed 'this admission', which he thought would have 'been of considerable importance had it come from higher authority' (Amherst to Canning, 12 February 1817, in BL IOR G/12/197 (Reel 2) F 237).

Discussions were interrupted with the arrival of the legates, Sulenge and Guanghui, who requested a private meeting. A vermillion edict written in the Jiaqing emperor's hand had just been received. The emperor thought there were too many people in the embassy and accordingly ordered that the band return to the ships. This demand, in Morrison's view, indicated the emperor's 'weak [and] capricious mind' (1820, p. 36). 
Staunton thought his objection was a 'very ungracious act' as the band was a 'harmless addition' to the embassy's amusement and was necessary for its 'public state' (1824, p. 56). Amherst stood firm. He told the mandarins that he was responsible for the band's behaviour and wellbeing and it was impossible to separate it from the rest of the embassy. The emperor's letter, Amherst noted privately, was written at a date prior to any formal discussions over the kowtow and before the emperor had any reason to suppose that Amherst was not going to perform the ceremony (Amherst to Canning, 12 February 1817, in BL IOR G/12/197 (Reel 2) F 238). Ellis (1817) noted ominously, it was impossible to avoid supposing that it was only the first in a series of trivial exceptions that were about to be taken to the Embassy' (p. 111). British attitudes towards the emperor's disposition changed at this time. The emperor, in Hayne's opinion, was 'an illiterate, debauched sot, timid and tyrannical' who, due to three attempts on his life, was 'frightened at his own shadow, so that we have nothing to hope from such a man' (n.d., vol. 2, p. 43).

Serious concerns arose that evening with the arrival of Sulenge and Guanghui in a highly agitated state, described by Jeffrey as being in 'a considerable fuss' (Jeffrey Amherst, n.d., n.p.). Amherst was asked, in a most abrupt manner, 'what is become of your ships?' (Staunton, 1824 , p. 56). Provisions had been sent to Dagu, but it was discovered that the ships had already left. Their departure, undertaken without imperial permission, was blamed on Amherst and was viewed as a 'great omission' on the part of the British (Staunton, 1824, p. 57). Concerned that they would be blamed by the emperor, the legates enquired how the embassy planned to return to England. Amherst's reply was cagey. He said that, as there had been no previous discussion on the question, he had assumed that the embassy was to follow Macartney's precedent and travel overland to Canton. The mandarins were informed that he had no authority over the movements of the ships, which were respectively under the command of the Royal Navy and the Company. ${ }^{11}$ An early departure, Amherst added, was thought expedient due to the danger of inclement weather but that decision was beyond his control.

11 Staunton, as president of the Select Committee, ordered Captain Ross, Commander of the Company ship Discovery, to follow the orders of Captain Maxwell until the latitude of the N.E. point of Shan-tung, when you will be permitted to separate from His Majesty's ships, and are to proceed towards Macao with the Investigator under your orders, and to execute such parts of the survey ... as you may find practicable, without giving any ground of suspicion or offence to the Chinese Government'. Orders were not to take a 'regular Survey' of the 'Gulf of Pe-chee-lee' but any 'observations' made will be 'exceedingly acceptable to the Honourable the Court of Directors' (Orders signed Geo. Thom. Staunton, HMS Alceste, 9 August 1816, in BL IOR G/12/196 (Reel 1) F 366). 
Guanghui became increasingly irritated. Informing Amherst that his behaviour in concealing the movement of the ships was highly improper, he blamed Morrison for wrongfully translating British intentions. Guanghui pointed his finger at Morrison, exclaiming, 'It is your fault!' (as quoted in Morrison, 1820, p. 37). Morrison, according to Staunton, 'very properly said, that if such was his opinion he must decline any further interpretation' (Ellis, 1817, p. 114). Amherst now intervened using all his diplomatic skills. Staunton was requested 'to express to both Mandarins his sense of the injustice done to Mr. Morrison, and to inform them that he considered such observations personally offensive to himself' (p. 115). Morrison was offered an apology, which was accepted. The fact that Guanghui would be held accountable by the emperor for not preventing the ships' departure was obvious to the British (Amherst to Canning, 12 February 1817, in BL IOR G/12/197 (Reel 2) F 242). Amherst said he would write a letter to the emperor explaining that the ships had to leave due to the dangers of remaining at anchor in the shallow waters of the Gulf. Ellis added, 'We could not be surprised at the dissatisfaction shewn by the Mandarins at the departure of the ships, and still less at our silence upon the subject' $(1817$, p. 115). The mandarin in charge of the ships at Dagu, the British were informed, had since been demoted (Morrison, 1820, p. 38).

The departure of the British ships without imperial approval was a major reason for the subsequent treatment of the embassy. News reached the Select Committee at Canton in late September 1816 that the emperor had made up his mind to refuse any presents and had given directions for the embassy to be dismissed at this time (Extract from Public Consultations 1816/17, 21 September 1816, in BL MSS EUR F 140/48). ${ }^{12}$

\section{August: Further Discussions on the Kowtow}

Chang-wei and Yin visited Amherst the following morning. An imperial edict had arrived with instructions to dismiss the embassy if the kowtow was not agreed to (Staunton, 1824, p. 59). Sulenge and Guanghui were too distressed to come themselves and had deputised Chang-wei and Yin

12 News of this had serious repercussions at Canton where permission to load the General Hewitt with teas was refused by the Canton authorities. A standoff with the Select Committee lasted some months. 
to deliver the emperor's message. Amherst said he would answer only to the legates but informed them that he was prepared to follow Macartney's precedent and enquired if a mandarin of equal rank would kowtow before a portrait of the Prince Regent. This, Chang-wei and Yin replied, was impossible, as Amherst would be in the presence of the emperor whereas the Chinese official would be paying homage to a mere picture (Amherst to Canning, 12 February 1817, in BL IOR G/12/197 (Reel 2) F 244). The proposal that a future Chinese ambassador at the Court of St James's kowtow in front of the British sovereign was also dismissed with the mandarins adding that they dare not suggest such a proposal to the emperor. Amherst called a halt to the meeting and said he would defer any further discussion on the kowtow until he met with the legates.

Sulenge and Guanghui arrived shortly afterwards. Staunton wrote that they appeared most dejected. Efforts were made to convince Amherst to kowtow by pointing out that the ambassadors of Japan, Siam and other independent countries all kowtowed before the Chinese emperor. Amherst recorded indignantly in his report that analogies made with the courts of Portugal or Russia would have been more appropriate. ${ }^{13}$ Amherst, accordingly, refused 'any comparison to be drawn between the King of Great Britain and the feeble states which surrounded the Chinese Empire' (Amherst to Canning, 12 February 1817, in BL IOR G/12/197 (Reel 2) F 245). 'These nations', Ellis reminded the legates, 'could neither be classed in point of civilization nor power with the English' (1817, p. 118). This point was accepted by the legates who stressed again that the British were being received by the court with far greater honours than any other country. Amherst refused to compromise. He told the legates that he would record and forward his proposals in a letter to the emperor, but was told it was not possible to communicate with the emperor in this way. Moreover, the legates said, they had already been chastised by the emperor and dared not anger him further (Morrison, 1820, p. 39). ${ }^{14}$ In that case, Amherst replied, he was left with no alternative but to return to England. Guanghui and Sulenge became most distressed at this turn of events and expressed their regret by saying repeatedly that such was 'the will of Heaven' (Amherst to Canning, 12 February 1817, in BL IOR G/12/197 (Reel 2) F 246).

13 Both of whom had refused to kowtow.

14 Morrison (1820) added that Amherst referred to the Kangxi emperor and the exception made at the time of the Ismailof Embassy where a mandarin kowtowed before an image of the Russian God, but Guanghui replied that, although he had heard of it, this was not in any authentic record. 
Guanghui and Sulenge's refusal to forward any of Amherst's letters to the emperor, in Staunton's (1824) opinion, shifted the responsibility for the outcome of embassy onto the Chinese, 'at least according to all European notions of diplomacy'. The Chinese would now be 'completely responsible for the rupture, if a rupture ensued' (p. 63). In the meantime, Guanghui and Sulenge told the British that some mandarins of an even higher rank were being sent to conduct the embassy. The embassy was halted and ordered to turn back to Tianjin.

\section{7-21 August 1816: The Continuation of the Diplomatic Impasse}

Chang-wei and Yin remained the chief interlocutors with the embassy. Morrison described Chang-wei as 'grinding and gnashing his teeth' due to the situation having become 'extremely stern and severe' (1820, p. 41). Amherst was informed that the embassy's dismissal was considered most undesirable and appeals were made to him to reconsider his decision on the kowtow. Perhaps he could humbly request the emperor's permission to follow the Macartney precedent and kneel on one leg as ordered by the British sovereign. Further, Staunton was asked to confirm that, while he was too young to remember whether Macartney had kowtowed, he had heard that Macartney had not. The emperor may be induced to dispense with the strictness of the ceremonial, in consideration of such a solicitation' (Ellis, 1817, p. 125).

Staunton was then subjected to a long harangue from one of the mandarins. The Jiaqing emperor was disappointed, Staunton was told, that he had not used his influence to pressure Amherst into performing the kowtow. This action was the least Staunton could do considering the gracious notice he had received from the Qianlong emperor. Amherst interrupted. Staunton's opinion, he said, had nothing to do with his orders, which he received directly from his sovereign (Ellis, 1817, p. 124). Agreement was reached finally with Amherst undertaking to kneel three times accompanied by three bows. Amherst concluded the meeting and retired with his suite for breakfast. 


\section{News of the Appointment of Heshitai and Muketenge to Take Charge of the Embassy}

Chang-wei and Yin paid another call immediately after breakfast with the news that the embassy was to proceed to Tongzhou where they would be met by two Tartar mandarins of the most senior rank who were taking charge of the embassy. The first was Heshitai (referred to as 'Ho' by the British) who held the title of gongye, translated by Staunton and Morrison as 'Duke' (Tuck, 2000, p. xxix). ${ }^{15}$ Heshitai was also the emperor's brotherin-law and a Manchu of the Bordered Yellow Banner (Tuck, 2000, p. xxix). The second mandarin was Muketenge, referred to by the British as 'Moo', who was the president of the Board of Rites and one of the most senior administrators of the empire (Tuck, 2000, p. xxix). ${ }^{16}$ Their specific orders were to instruct Amherst in the performance of the kowtow before permitting him to proceed to Peking.

Heshitai and Muketenge's appointment indicated to the British that Guanghui and Sulenge had failed in their handling of the embassy (Davis, 1841, p. 97). Amherst was informed that he was due to meet the senior mandarins where he was expected to perform the kowtow before a yellow screen and a dragon tablet (Staunton, 1824, p. 66). Such a rehearsal, Amherst thought, was a Chinese trick to induce him to perform the ceremony in a public space (Amherst to Canning, 28 February 1817, in BL IOR G/12/197 (Reel 2) F 254). Chang-wei and Yin next requested Amherst to practise the same ceremony he intended to perform before Heshitai and Muketenge at Tongzhou in front of them. Amherst 'flatly refused' and told them that the ceremony he would perform was a serious matter and was reserved for the emperor's presence. He added that he proposed to inform the emperor of his intentions in a personal letter. The offer 'of a written engagement for its performance', Amherst noted, 'seemed to give them great satisfaction' (Amherst to Canning, 28 February 1817, in BL IOR G/12/197 (Reel 2) F 255). He proposed to kneel on one

15 He was awarded the title due to his services in the defence of the Imperial Palace during a rebel attack in 1813 .

16 Muketenge was also a Manchu of the Bordered Yellow Banner. Representing the highest rank of the Eight Banners, members of the Bordered Yellow Banner comprised the elite of the emperor's bodyguard (see Elliott, 2001, pp. 81, 366). 
knee three times, and to thrice bow each time (Staunton, 1824, p. 67). The letter was composed by Morrison and signed by Amherst. Its delivery to the mandarins resulted in permission for the embassy to proceed to Tongzhou, arriving there on 20 August.

\section{Davis is Visited by a Cantonese Mandarin}

While Amherst was engaged in discussions with Chang-wei and Yin, Davis received an unexpected visit from a Cantonese mandarin that was regarded by the British as an intelligence gathering exercise. The mandarin wished 'to speak on the subject of the existing discussions', referring to the kowtow (Davis, 1841, p. 95). Davis informed him that he had no authority to speak on behalf of the ambassador but could inform the mandarin of the 'understood declaration' that the British could never perform the ceremony. This statement was met with a list of possible ramifications if Amherst did not agree to the kowtow. First, it would be a great pity if the British left China without seeing the emperor and the king would be 'incensed' when he found out how the British were conducting themselves in their negotiations with the Chinese. Davis was next asked about the ceremony he would perform in the presence of the British sovereign. Davis replied that it would not be the kowtow and that he wished to have no further discussion on the matter. The mandarin then raised the importance of the Canton trade to Britain, which was permitted only with the benevolence of the Chinese emperor. The trade, Davis replied, was mutually beneficial to China and Britain. The mandarin then departed, having failed, Davis believed, to learn any new intelligence about British plans (Davis, 1841, p. 97).

\section{August: Arrival at Tongzhou, 12 Miles from Peking and Nine Days Before the Reception at Yuanmingyuan}

The British boats anchored at Tongzhou at five o'clock in the afternoon. Guanghui and Sulenge called on Amherst to enquire further about the ceremony Amherst proposed to perform before the emperor. They said the emperor was in a very good mood and it would be a shame if some mutual 
arrangement could not be negotiated — everything would go smoothly once Amherst agreed to kowtow (Amherst to Canning, 28 February 1817, in BL IOR G/12/197 (Reel 2) F 254). The emperor's decision to send two mandarins of exalted rank to henceforth conduct the embassy was proof of his regard and an acknowledgement of the superior status of the British sovereign compared to the tributary princes. Amherst referred once more to the Macartney precedent, whereby he would kowtow if a Chinese minister of rank performed the same ceremony before a portrait of the Prince Regent, or if an imperial guarantee was received that any future Chinese ambassador at St James's would perform the kowtow in front of the British sovereign. He emphasised further that a British ambassador would never perform an act that could be construed by the Chinese as an act of homage from a dependent prince (Ellis, 1817, p. 140).

Guanghui and Sulenge were disappointed. Amherst reassured them that the exalted rank of the new mandarins was of little concern and that his decision was final. He would never be persuaded by any mandarin, no matter how exalted his rank, to change his mind (Ellis, 1817, p. 141).

The legates next made a fateful suggestion. Amherst was free to 'make any report he pleased on his return to England' regardless of whether he performed or did not perform the kowtow. The implication that Amherst would be prepared to lie before his sovereign met with predictable British outrage (Amherst to Canning, 28 February 1817, BL IOR G/12/197 (Reel 2) F 256). Amherst, Ellis (1817) pointed out, had 'seventy-four witnesses with him who would state the truth' (p. 141). ${ }^{17}$

17 The Chinese claimed that Macartney kowtowed before the Qianlong emperor at the second reception when only he and the Stauntons, as well as the Chinese interpreter Mr Plumb, were present. The fact that this was a tightly inclusive group, where a performance of the kowtow would most likely be kept secret, hardly needs to be pointed out. If Macartney had kowtowed, the three witnesses could be relied on to keep to the 'official' British story. The presence of other visiting envoys, however, as well as the close proximity of 10 Russians at the College in Peking, guaranteed that news of Macartney kowtowing would have eventually found its way to Europe, which, as noted earlier (see fn. 6 of this chapter), is what Rockhill (1905, p. 31) claimed. 


\section{August: New Mandarins Arrive to Take Charge of the Embassy, Seven Days Before the Embassy's Arrival at Yuanmingyuan}

The two senior mandarins sent to witness Amherst rehearsing the kowtow arrived on 21 August. Heshitai was described as 'a young man of few words and of very firm character' (Morrison, 1820, p. 44). ${ }^{18}$ Muketenge was 'a thin old man' who never spoke and was nicknamed the 'Silent Moo' by the British (p. 44). Their high rank impressed Morrison who noted that the embassy had three 'Shang-soo or Presidents' assigned to negotiate with the ambassador out of a total of seven in the Chinese Government (p. 44). ${ }^{19}$ Amherst arranged to meet them the next day.

The British dined together that evening under a veranda in the court. Hayne wrote:

Having got our plate, glass, and wine ... we made a good display to the astonishment of the staring crowd who were mounted up in the surrounding trees overlooking our Court walls ... watching every movement we made. (n.d., vol. 2, p. 57)

The meal was interrupted when Chang-wei appeared with news that a deputation of mandarins was waiting to call on the ambassador. Amherst, Staunton, Ellis and Morrison left the table and went to Amherst's apartment to greet them. Their visit, Davis wrote, 'sounded extremely formidable'. He added, 'it was right we should be duly prepared for such celestial colloquy sublime' (as quoted in Hayne, n.d., vol. 2, p. 57).

\section{The 'Lads of Mougden'20}

Six mandarins, dressed in their ceremonial robes, arrived. Some wore blue buttons and peacock feathers. Staunton and Ellis went forward to meet them but, much to their astonishment, were ignored as the mandarins

18 Morrison further described Heshitai as 'about 35 years of age, of the middle size; stout, and possessing apparently great bodily strength and warmth of temper' (1820, p. 44).

19 Morrison added that 'all three were destined to be dismissed from their employment' on account of the embassy (1820, p. 44). 'Shang-soo' is likely to be shangshu.

20 Mukden, present-day Shenyang. 
'brushed rudely' past them and made straight for the sitting room where they 'seized on the chief seats without waiting for an invitation' (Staunton, 1824, p. 74). Davis wrote:

We all stood aghast ... when this half-dozen of savages rushed past without so much as a look, and proceeding to seize the six highest places, seated themselves down at once. (1841, p. 107)

Amherst, however, spectacularly 'out-manoeuvred them by taking the principal seat' at the other end of the room.

The mandarins, whom Jeffrey described as 'understrappers', were particularly haughty and acted in an 'exceedingly rude and overbearing manner' (Jeffrey Amherst, n.d., n.p.). ${ }^{21}$ They enquired which of the Englishmen gathered before them was the ambassador for they had come to inform him that he was expected to perform the kowtow in front of Heshitai the following day. Amherst replied in an equally authoritative voice that he would only discuss such matters with Heshitai and Muketenge. The mandarins pretended not to understand and continued with a harangue about the importance of the ceremony to the Celestial Empire. Amherst repeated his answer in an even louder tone after which 'they [the mandarins] bounced up and strutted out of the room' (Davis, 1841, p. 108).

The meeting lasted only 10 minutes. The British made a point of showing their displeasure by 'treat[ing] them on their departure with all the disrespect we could' (Jeffrey Amherst, n.d., n.p.). The band was prohibited from playing and the marines were ordered to withhold their salute. The 'grotesque piece of diplomacy' they had witnessed astonished the British who remained in their seats for some time in what can only be interpreted as a state of shock. The group of six mandarins hereafter acquired a new nickname and were referred to by the British as the six 'lads of Mougden' (Davis, 1841, p. 108). Their attempts to bully the British into complying with the ceremony reinforced a fundamental difference between Western and Chinese diplomacy where negotiation over disputes was not an option. Any preconceived notion the British may have had of a fruitful diplomatic encounter was finally dispelled. Davis wrote:

21 The Shorter Oxford English Dictionary defines an 'understrapper' as 'a subordinate; an underling'. 
Nothing but the greatest ignorance of the character of Europeans could have led the Chinese to hazard such an attempt ... Herein consists much of their weakness in negotiations; they are too proud to learn any thing about us, while we foreigners ... never lose an opportunity of studying them in every relation of life ... That 'power' which consists in 'knowledge', therefore, preponderates on our side. We know, above all, that the most complete want of faith, the most unblushing perfidy, is one part of the Chinese system in their negotiations with strangers; and unless this be carefully kept in view during the existing crisis, they may play us some sad tricks. (1841, p. 109)

British apprehension was reflected with Ellis having second thoughts over the wisdom of refusing to perform the kowtow ceremony. The fact that the kowtow had become the only question under negotiation was extremely worrying, but the dice was thrown and the British had to stand by their decision (Ellis, 1817, p. 145). Abel thought the 'despicable presumption of these men gave a foretaste of the treatment that His British Majesty's Representative afterwards experienced from their superiors' (1818, p. 93).

Amherst, who wished to sleep on board his boat, was requested with some urgency by Chang-wei and Yin to sleep ashore in the temple apartments arranged for him. Much to their relief, Amherst promised to do so once his furniture had been delivered. 'The Emperor', they said, 'has very long ears' and would suspect them of 'making false reports and punish them for it' (as quoted in Hayne, n.d., vol. 2, p. 61). Davis added in a superior tone, 'We were of course too polite, and had too sincere a respect for his Majesty, to dispute the application of this asinine attack' (as quoted in Hayne, n.d., vol. 2, p. 61). Amherst complained about the mandarins' rudeness earlier in the day and pointed specifically to the insult paid to Staunton when they pushed past him. Chang-wei explained that this behaviour was typical of those mandarins who remained at court and who had never served in the provinces; he and Yin had also been ignored, as had his offer to escort them to meet the embassy (Staunton, 1824, p. 146). 


\section{August: First Meeting with Heshitai and Muketenge}

The meeting with the imperial commissioners, Heshitai and Muketenge, was arranged for midday. Amherst prepared himself for a termination of the embassy but still held a vague hope and a belief that a direct appeal to the emperor 'was the only way to obviate such a proceeding' (Amherst to Canning, 28 February 1817, in BL IOR G/12/197 (Reel 2) F 258). Ellis proceeded to draw up a letter that was carefully translated into Chinese by Morrison. With such in his possession, Amherst wrote, he accepted the invitation to a conference but stipulated 'that I should not be called upon, for either practice or performance of any Court ceremony' (Amherst to Canning, 28 February 1817, in BL IOR G/12/197 (Reel 2) F 258). His letter informed the emperor:

The great affairs of empire being best conducted by precedent, his Royal Highness has instructed me to approach Your Imperial presence with the same outward expression of respect that were received by your dignified father Kien-Lung [the Qianlong emperor], from the former English Embassador, Lord Macartney, that is to say, to kneel upon one knee and to bow the head, repeating this obeisance the number of times deemed respectful. (Lord Amherst to the Emperor of China, August 1816, in Ellis, 1817, p. 497, Appendix 4(a))

Such a 'particular demonstration of veneration from English Embassadors' was shown only to Chinese emperors (Lord Amherst to the Emperor of China, August 1816, in Ellis, 1817, p. 497, Appendix 4(a)). 'I shall consider it the most fortunate circumstance of my life to be enabled thus to show my profound devotion to the most potent Emperor in the universe' (Lord Amherst to the Emperor of China, August 1816, in Ellis, 1817, p. 497, Appendix 4(a)). The letter concluded with a request that Amherst be received in an imperial audience to personally deliver the Prince Regent's letter. He hoped the emperor would 'graciously consider the necessity of my obeying the commands of my Sovereign' (Lord Amherst to the Emperor of China, August 1816, in Ellis, 1817, p. 497, Appendix 4(a)).

The meeting with Heshitai and Muketenge was due to be held at the Literary Hall situated in a small building in the middle of the city, some two miles from where the boats were moored (Morrison, 1820, p. 47). 
Torrential rain was falling and the road was terrible. Amherst and the commissioners travelled in palanquins after refusing some 'primitive carts' drawn by mules. Chang-wei and Yin were fearful that this honour would come to the attention of the emperor given the close proximity of Tongzhou to Peking.

The Hall of Audience, the British noted, was 'a mean, dirty looking house, with the roof overgrown by grass' (Davis, 1841, p. 114). 'Crowds of mandarins' met the British in the courtyard where Amherst, Staunton, Ellis, Morrison and Jeffrey were conducted into a small hall to meet the imperial commissioners (Jeffrey Amherst, n.d., n.p.). The rest of the embassy had to wait either in the pouring rain or face the risk of 'suffocation in a crowded room of ill-savoured and importunate Chinese' (Abel, 1818, p. 96).

Heshitai, Muketenge, Sulenge, Guanghui and the six 'Lads of Mougden' were waiting to receive the British. Amherst was informed by Heshitai that he and Muketenge were sent to instruct Amherst on performing the ceremony and that he now wished to see Amherst perform it correctly. Amherst reiterated that he had never intimated that he would perform the ceremony and had been ordered by his sovereign to follow the same ceremony as Macartney that had been acceptable to the Qianlong emperor. Heshitai replied:

What happened in the fifty-eighth year [1793] belonged to that year; the present is the affair of this Embassy, and the regulations of the celestial empire must be complied with; there is no alternative. (as quoted in Ellis, 1817, p. 148)

Amherst added he was confident that the Jiaqing emperor would accept the ceremony performed by Macartney before his father. Heshitai responded vehemently and informed Amherst:

As in heaven there are not two Suns, so on earth there are not two Sovereigns. The Great Emperor is Teen-tsze, 'the Son of Heaven'; before him all Kings should bow down. (as quoted in Morrison, 1820, p. 48) 
The commissioner then turned towards Morrison, who had earlier been seen reading a work by Confucius, and continued:

You know it ... [the ceremony] has existed from the highest antiquity, and cannot be altered. Without the performance of this ceremony, the Embassador and his tribute will be ... rejected and cast out. (as quoted in Morrison, 1820, p. 48)

Heshitai, Morrison (1820, p. 48) noted, gestured with his hands in an outward motion as he pronounced the last word.

This belief, in the British view, was an 'absurd pretension'. Regardless of such absurdities, Amherst wrote, 'I did not think this a reasonable moment to assert the perfect equality of my own Sovereign' (Amherst to Canning, 28 February 1817, in BL IOR G/12/197 (Reel 2) F 258). Rather, he praised the emperor as 'one of the greatest Sovereigns in the world' and it was for this reason that the Prince Regent had sent him to compliment His Majesty (Morrison, 1820, p. 48). Heshitai, Morrison (1820, p. 48) reported, smiled at this moment, and gave Amherst a small purse from his belt. The Chinese Government, Heshitai responded, considered the British with greater esteem than other nations because they spoke Chinese and read Chinese books. This was demonstrated by the honour bestowed on the British of delegating mandarins of such high rank to escort the embassy (Staunton, 1824, p. 81). Nevertheless, the British must kowtow. Amherst remained calm and dignified. The British position on the ceremony was explained yet again. He told Heshitai that he had already written a letter informing the emperor of his position, but Guanghui now confessed that he had not dared pass it on to the authorities.

After 20 minutes, the British sensed the meeting was drawing to a close. Enquiring if another meeting was planned, Heshitai told Amherst that he never paid visits and that the present meeting was equivalent to one held before the emperor. He added, 'lips quivering with rage', that the embassy would be dismissed if Amherst did not comply with the proper ceremony (Ellis, 1817, p. 149). At this, Amherst placed his sealed letter to the emperor into Heshitai's hands and turned to leave the room. His actions, the British were pleased to note, had the desired effect. Heshitai was taken by surprise and the 'lofty tone assumed by the tartars was checked as their attention was arrested by the sight of the Emperor's name' (Amherst to Canning, 28 February 1817, in BL IOR G/12/197 (Reel 2) F 262). The British were shown a little more civility with the Chinese escorting them to the door. Amherst was confident that 'negotiation might be considered 
as still remaining open' despite all that had taken place at the meeting (Amherst to Canning, 28 February 1817, in BL IOR G/12/197 (Reel 2) F 262).

Heshitai's acceptance of Amherst's letter was encouraging, although doubt remained of it ever reaching the emperor. In the event that it did, the British hoped it might persuade the emperor to accept their position on the ceremony. If, on the other hand, permission to proceed to Peking was denied, the conciliatory tone of the letter was thought to at least ensure a civil return to Canton 'and allow us to part pretty good friends' (Davis, 1841, p. 116).

\section{August: Amherst's Letter Dismissed}

Chang-wei called on Morrison in the morning with news that Amherst's letter was being returned. The mandarins, Morrison was informed unofficially, had opened the letter on a pretext of legal protocol over the manner in which the emperor's address was written on the cover; while Amherst's title 'Ambassador' had been included, his name had not. Such an omission, the British were told, was defined under Chinese law as an anonymous address to the emperor and could never be delivered (Ellis, 1817, p. 150). The letter, Chang-wei admitted, was a 'very good one', but it could not be forwarded to the emperor (Staunton, 1824, p. 82). He enquired once again about Amherst's 'final sentiments respecting the ceremony', but Morrison told him that this would only be discussed after the ambassador had received a communication from the emperor (Staunton, 1824, p. 82).

Further strategic discussion took place among the British. As noted previously, Ellis, by this stage, was having serious doubts about the wisdom of refusing to kowtow. He wrote, 'The bearing of my mind, uninfluenced, and unaided by local knowledge, [began] to regret that the reception or dismissal of the Embassy should entirely turn upon the question of ceremony' (1817, p. 151). Regardless of Ellis's reservations, Staunton decided it was expedient to complain formally about the mandarins' refusal to send the letter to the emperor, pointing out that it was an official document and it would be the mandarins' responsibility should the embassy be expelled (Staunton, 1824, p. 82). A short statement on the exchange of presents 'and other arrangements' was planned in the hope of preserving good relations between Britain and China. 
Negotiations at this time took place mainly between Chang-wei and Morrison, a fact that later drew criticism from one British commentator who pointed out, correctly, that Morrison was an interpreter and not vested with authority to conduct a diplomatic dialogue (Anonymous, 1818). ${ }^{22}$ Chang-wei, meanwhile, made a second call later in the morning and handed Amherst's letter to Morrison, requesting that he add Amherst's name to the front cover. Heshitai had agreed to forward the letter to the emperor if this was done. Chang-wei again urged that Amherst comply with the ceremony but admitted privately to Morrison that he thought too much was being made of the issue. Morrison wrote:

He did not seem at heart favourable to submission; he always called it 'their Tartar ceremony', and disclaimed the idea of it being Chinese. 'They were', he said, 'most tenacious of it; so much so, that old infirm people, who could no longer kneel or stand, were caused to raise themselves from the seat on which they sat, and fall down again with a bump, the number of times that others knocked their head'. (1820, p. 50)

Chang-wei explained that because the British had come to China in a voluntary capacity, it was the ceremony that was valued and not the presents. He added, significantly, that the Chinese could not make an exception for the Amherst Embassy as this would set a precedent for future diplomatic missions. Morrison replied that such ancient rules were no longer applicable to powerful nations-a good host would permit the British to observe their own ceremonies that, in turn, would serve to only increase the esteem of the emperor among foreign nations (Morrison, 1820, p. 51).

Chang-wei returned to the business at hand and suggested that Morrison change the wording in the letter from 'the King of England had cultivated amity with Keen-lung' to 'Keen-lung had treated the King of England amicably' (Morrison, 1820, p. 51). The British agreed to this change in the wording and also to the inclusion of Amherst's full name on the cover. Chang-wei next requested that the phrase referring to Amherst performing

22 A delicate enquiry into the embassies to China and a legitimate conclusion (1818) is an anonymously authored 30-page pamphlet published in response to the failure of both the Macartney and the Amherst embassies. Morrison was specifically criticised for not accurately relaying some of the mandarins' comments, thereby placing Amherst at 'his mercy'. The author argued that, had Amherst been properly informed, he would have immediately broken off negotiations and returned to England. Morrison's role was questioned: 'what right or authority [does] Mr. Morrison, [have] acting as interpreter?' (p. 2). 
his ceremony on one knee be changed to 'two knees'. Morrison dismissed this proposal as childish because such a change would render Amherst's letter as useless (Morrison, 1820, p. 51).

Chang-wei now handed Amherst an extract from the imperial records that not only recorded that Macartney had performed the kowtow, but also that the Jiaqing emperor remembered his doing so. Ellis (1817) admitted, 'With this imperial assertion before us, however false or erroneous, it will be difficult, in the event of a renewed discussion, to press the precedent of Macartney' (p. 154).

Staunton, in a rare reference to Manning, described a private conversation Manning had held with an inferior mandarin who had visited him ostensibly on the pretence of grounds of civility. Manning soon realised his real purpose was to acquire some further intelligence on the intentions of the British regarding the ceremony. Manning listened to what the mandarin had to say before informing him of the reasonableness and the 'immutability' of the British decision (Staunton, 1824, p. 83).

\section{August: An Attack on Staunton}

Chang-wei visited Morrison early the next morning. Heshitai had refused to send Amherst's letter to the emperor and would only do so if the ambassador declared that he was prepared to perform the kowtow. The emperor, the British discovered, had seen the letter but had decided not to make a formal response, confirming instead that he had witnessed Macartney performing the kowtow before the Qianlong emperor. Amherst diplomatically suggested that because Macartney's ceremony was so similar to the kowtow that the Jiaqing emperor had probably mistaken one for the other. Further, he probably viewed the ceremony at some distance where his view was obstructed by the crowd and where Macartney's long robes would 'have the effect, in the eyes of His Imperial Majesty, of a salutation such as his Imperial Majesty required' (Amherst to Canning, 28 February 1817, in BL IOR G/12/197 (Reel 2) F 264).

Chang-wei paid yet another visit to Morrison in the afternoon. Amherst wrote, 'New matters [now] arose, such as to make every step taken by myself in conjunction with my colleagues the subject of serious reflection and deliberation' (Amherst to Canning, 28 February 1817, in BL IOR G/12/197 (Reel 2) F 264). The emperor, Morrison was informed, had 
received a report from Canton informing him of the presence of 'mere traders' in the embassy suite- the embassy, therefore, was not legitimate. Staunton specifically:

Had been appointed ... in consequence of his knowledge of the usages of the Celestial Empire; but [knowing these he] failed in his duty ... as he did not inform the Embassador of them, and persuade him to comply with the ceremony. (Morrison, 1820, p. 52)

Amherst understood that the situation was now serious as British trade was being directly threatened by the Qing court. Chang-wei suggested that Staunton's time at Canton was limited unless he gave Amherst proper advice. Stories of Staunton's wealth had reached the court with reports of splendid apartments, fine aviaries, horses at Macao and that Staunton had bought his position in the embassy (Staunton, 1824, p. 85). Such information was symptomatic of the inaccuracies and shortcomings of Chinese intelligence as its facts were not true of Staunton but referred rather to another Englishman, Thomas Beale, a wealthy private trader and long-term resident of Canton who was also the Honorary Prussian Consul (Staunton, 1824, p. 89). ${ }^{23}$ The British tried to stop this very 'improper harangue'. Amherst asserted that he resented such accusations, adding that the British Government and the Prince Regent could appoint whom it liked to its embassies. Amherst took the initiative and asked Chang-wei to provide a set date of departure if the embassy was not to be received. Chang-wei ignored the request and turned the conversation back to the topic of the ceremony, which was argued over again at some length with no resolution.

Chang-wei paid another call in the early evening. The Chinese wanted letters written to the captains of the British ships ordering them to stop at the next port they visited. Amherst agreed. The British suspected that the report regarding Staunton was written by the acting viceroy of Canton on the advice of a Portuguese judge whose 'badness of character' as well as 'his determined hostility to the English' were sufficiently known to justify the suspicion (Ellis, 1817, p. 161). Amherst and the commissioners refused to enter into any discussion on the matter, although Morrison privately informed Chang-wei that the report was of an absurd and scandalous nature (Staunton, 1824, p. 87).

23 Eastberg (2009) noted that Beale had made his fortune through the private opium trade. The association made by the Qing court of Staunton with Beale, Eastberg suggested, was a scheme engineered to associate the embassy with opium smuggling (p. 187). 
The British read the personal attack on Staunton as a devious Chinese attempt to intimidate them and as a tactic designed to influence favourable outcomes. Staunton believed that such intelligence about him would never have been brought to the attention of the British had it not been for the impasse of the ceremony. He wrote:

The Chinese know perfectly well that the rank and station of the East-India Company's senior servants at Canton is perfectly distinct from that of private merchants, and that the offices they hold are of a nature fully equivalent to those of their own magistrates, and this they have even specially acknowledged in a public edict ... it is their object to seize upon any pretext to depreciate an Embassy they are threatening to dismiss; and thus their pretended objections to its constitution may be accounted for. (1824, p. 88)

\section{August}

Chang-wei informed the British that an imperial letter to the Prince Regent was in the process of being composed and it was planned to hand this to them in the event of the embassy's dismissal. Arrangements for the reception of the Prince Regent's presents also had to be organised. Changwei gave Morrison some hope that the presents might still be accepted and told him there were still some 'enlightened men in the emperor's councils' (Staunton, 1824, p. 90). Heshitai, however, was conspicuous by his absence and silence. The British had to sit tight and await events.

Chang-wei paid Morrison two more visits that day. News from his friends at the court reported that the emperor was 'extremely enraged' over the disappearance of the British ships. Further, the local viceroy had ordered the doubling of the guard around the British embassy to prevent Staunton from engaging in any communication with 'evilly disposed Chinese'. Staunton found this news 'rather mysterious and alarming', but as the British were due to receive a copy of the edict the next day, he reserved his opinion until he had read it (Staunton, 1824, p. 91). The presence of the Chinese troops, in Abel's opinion, kept the British in 'a state of uneasy feeling' but failed to alter Amherst's decision on the ceremony (Staunton, 1824, p. 97). 
Meanwhile, reports of 'Two Russians, and a Frenchman in the service of Russia' hovering near the British quarters reached the British. They wore Chinese dress, spoke in French and were from the Russian College at Peking, but were prevented by the Chinese guards from getting close to the British (Staunton, 1824, p. 83). On the first day, the Frenchman managed to strike up a conversation with 'Vincent, the Negro drummer of the band' (Staunton, 1824, p. 83). He told Vincent that he had been in China for nine years and wished to talk with Amherst, but the British thought it best not to encourage any communication with him or the other missionaries (Ellis, 1817, p. 162). The motive for the visit was not known. The fact that Chinese troops prevented them from contact with the British suggested that they had not been sent by the court. On the other hand, it may have been a genuine attempt to engage the British for the latest news on international events.

\section{August: Amherst is Confronted with a 'Severe Test'}

Reports from the acting viceroy of Canton and the viceroy of Peking reached the British in the morning. The Canton report was a public version and contained none of the 'disparaging insinuations' mentioned by Chang-wei. On the contrary, Staunton wrote that it was favourable both to himself and to the embassy (1824, p. 92). But the report from the viceroy of Peking referred specifically to Staunton as 'an object of suspicion' as well as 'a person who certainly has the power, and may have the will, of combining with the natives against the government' (as quoted in Staunton, 1824, p. 92). Staunton attributed the suspicion and hostility shown towards him to the unsettled political state of northern China:

The province in which we are in, has been lately in a state of open rebellion ... and estimating the invariable jealousy and suspicion, which, in the most favourable and quiet times, the Chinese look upon foreigners, especially the English, and most of all, those who are acquainted with their language, and are therefore, supposed to have the means of detecting the real circumstances of the country;-it may perhaps be pronounced that there is nothing very extraordinary in the Pekin viceroy's edict. (1824, p. 92) 
The fact that the British were permitted to read the document suggested an alternative interpretation-a deliberate Chinese attempt at intimidation. Staunton thought that 'the rejection of the Embassy [was] no longer the worst of the contingencies which may be apprehended' (1824, p. 93). Rather, there was a serious possibility that Staunton could be arrested. Staunton warned Amherst that the embassy now faced a 'severe test' (p. 93). Amherst, acknowledging Staunton's advice, wrote Heshitai a letter requesting specific notification as to whether or not the emperor intended to admit the embassy or expel it (p. 93).

Davis and Hayne delivered Amherst's letter to Heshitai's quarters where they handed it to Chang-wei. Amherst accepted an invitation to visit Heshitai the following day where a marked change in the commissioner's attitude towards the embassy was noted. Bullying had obviously not worked and Staunton thought the time had come for the British to 'decide finally upon the question of submission or resistance' (p. 94).

\section{Amherst's Initial Thoughts on Performing the Kowtow}

Some of the British read Heshitai's conciliatory gesture as an encouraging sign. The idea of performing the Chinese ceremony was even considered if the court gave a guarantee on the opening of negotiations on the embassy's goals. Amherst and Ellis were 'strongly against ... closing the door to negotiation while anything like a hope remained of any of the objects of the Embassy being attained by concession' (Staunton, 1824, p. 94). Compliance, in their view, was 'preferable to damaging British interests at Canton by allowing the mission to fail' (Staunton as quoted in Tuck, 2000, p. xxxi). Further, Amherst, it appears, was following Lamiot's advice to delay as long as possible in giving into Chinese demands. ${ }^{24}$ Staunton, however, stood firm on the decision not to kowtow, arguing that its performance would represent Britain's submission to the Jiaqing emperor, which would irrevocably threaten British honour and independence at Canton. He realised that being granted a mere audience with the emperor would serve no purpose and would result in only a few ceremonial pleasantries, at best, with no scope for serious negotiation

24 Lamiot's advice, as noted in Chapter 6 of this study, was referenced in Amherst's 'Notes on policy to be pursued by the British Embassy to China' (BL MSS EUR F 140/36). 
on British goals. Staunton's stand on the kowtow question, however, provides the evidence for Tuck (2000) and other historians to blame him specifically for the failure of the Amherst Embassy.

\section{August: Meeting with Heshitai}

The conference between the imperial commissioner and Amherst held on 27 August 1816 had important repercussions for the future conduct of the embassy. Heshitai had concluded that Amherst, 'might be induced by certain concessions' to kowtow (Ellis, 1817, p. 195). The British were received with much civility (p. 169). Heshitai, Muketenge, Sulenge and Guanghui rose to greet the British when they entered the inner court. The British were conducted to their chairs, which were placed on the left side of the courtyard. Heshitai took the upper seat, while Amherst sat in the chair on the right. Such an arrangement, Staunton noted, placed Amherst opposite Sulenge, while Morrison was seated so far down the line that communicating with him was impossible. Accordingly, Heshitai called for another chair for Morrison to be placed alongside Amherst. All the other mandarins, including Guanghui, stood.

Heshitai began the conference with the customary polite questions enquiring how far the embassy had travelled and the distance between Britain and China. He then turned to the topic of the ceremony and wanted to make sure that Chang-wei had adequately explained all its details. The emperor was insistent, Heshitai explained, that Macartney had kowtowed to his father and would accept no other form of ceremony (Amherst to Canning, 28 February 1817, in BL IOR G/12/197 (Reel 2) F 265). Although Heshitai spoke in a more conciliatory tone, Staunton thought his displeasure was never far from the surface. The exalted rank of the emperor, Heshitai maintained, outranked the status of a king. Amherst replied that his allegiance was to his own sovereign. Heshitai told Morrison, 'take care how you persist, lest you expose your king himself to the emperor's displeasure' (as quoted in Staunton, 1824, p. 96). Staunton (1824) commented that Morrison 'very properly checked the duke immediately, by saying that he did not dare to interpret to the Ambassador such a remark' (p. 96). Morrison's decision not to inform Amherst of this fact once again incited later British criticism in a review of the embassy (Anonymous, 1818, p. 4). 
Heshitai, attempting to 'deflect tensions', turned his attention to Jeffrey and called the boy to his chair. Jeffrey wrote that he 'condescendingly ... [gave] me with his own hands four purses and his fan upon which he wrote some Chinese characters' (Jeffrey Amherst, n.d., n.p.). Davis was sceptical of the mandarin's kindness and thought it was proof of 'the low estimate which the Chinese generally entertain of European intellects and feelings, to suppose for a moment that they could be influenced in such a way' (Davis, 1841, p. 137).

The British took the opportunity to raise some of their objectives with Heshitai, specifically, the feasibility of opening consular representation in Peking, thereby enabling direct communication between the British merchants at Canton with one of the tribunals of the emperor's court. The emperor, Staunton pointed out, had always 'professed to extend his regard and protections to foreigners' (1824, p. 97). The British desired only those rights accorded to the 'meanest of the emperor's own subjects' who had the right to appeal through tribunals up to the highest authority to the emperor himself (p. 97). Heshitai thought this was a reasonable request and assured the British that he would be their 'friend and advocate' on this or on any other issue as long as they complied with the ceremony: 'Comply with the Tartar ceremony, and I am your friend at Pekin' (as quoted in Ellis, 1817, p. 170). But, he added, he could not anticipate the emperor's response to British demands:

It might as well be asked of him, whether he thought it would rain or thunder to-morrow. The ways of the Son of Heaven were, like those of Heaven itself, inscrutable. (as quoted in Morrison, 1820, p. 54)

Testament to what was at stake, Amherst told Heshitai that he would reconsider his decision on the ceremony and would give a final answer in the afternoon.

\section{The Final British Decision on the Kowtow}

The British discussed the expediency of complying with the ceremony on return to their compound. Amherst and Ellis thought a performance of the ceremony in the emperor's presence was expedient if there was a possibility of the goals of the embassy being discussed. Staunton's (1824) memoirs explained their attitude in the context of the 'considerable sacrifice of 
private and personal feeling, to what they conceived to be the line of their public duty' (p. 99). Their approach, according to Staunton, was the result both of Heshitai's offer of support on one hand, and recent attempts to intimidate him personally and harm British commercial interests at Canton on the other (p. 100).

Amherst thought that his position was more complicated than it had appeared at the start of his embassy. Staunton's initial briefing on the kowtow, given on board the ships before the embassy landed in northern China, did not reflect on the possibility of either harm to the Company and trade at Canton, or on the contingency of a personal attack on Staunton as the Company's most senior executive. Amherst concluded:
Such a result would indeed have produced the very mischief against which I have been specially cautioned. Not only former grievances would not have been removed, but new misunderstandings would have arisen, and new evils would have been incurred. (Amherst to Canning, 28 February 1817, in BL IOR G/12/197 (Reel 2) F 268)

Amherst now asked Staunton if he had changed his mind on the potential risks to the Canton trade if he went ahead and kowtowed before the emperor. Staunton realised that the responsibility for the future of the embassy now fell to him and decided to consult with the other Company members of the embassy from Canton. He wrote:

Four of the five gentlemen who accompanied me had resided nine or ten years in China, and possessed such acknowledged talents, judgment, and local experience, as must necessarily entitle their opinions to considerable weight; and the fifth, Mr. Davis, though a young servant of the company, had displayed talents, and evinced a zeal in his application to the study of the language, which entitled his opinions to an attention beyond his years. (1824, p. 102)

Toone, Davis and Pearson were strongly against complying with the ceremony. Morrison and Manning had their reservations. ${ }^{25}$ Morrison was strongly against the kowtow in principle, but thought on this occasion that Company interests might justify compliance (Ellis, 1817, p. 172,

25 Manning, as noted in Chapter 4 (fn. 6), had performed the ceremony of kowtow before the 'Grand Lama' (who was seven years of age) at Lhasa during his visit to Tibet in 1811 (Markham, 1876, p. 265). A distinction needs to be made here between Manning, as a private individual travelling in a non-official capacity, and Amherst, who was an ambassador appointed by the British sovereign. 
note). On the conclusion of the consultations, Amherst decided to accept Staunton's advice and that of his colleagues and refuse to perform the prostration ceremony. He was swayed by Staunton's argument that to kowtow would not only represent a humiliating back down from the British position but would also 'encourage the local government at Canton to assume a tone of official superiority fatal to the independence of the trade' (Amherst to Canning, 28 February 1817, in BL IOR G/12/197 (Reel 2) F 270). Amherst wrote a note immediately to the mandarins informing them of his final decision not to kowtow. The historian Tuck (2000) has noted that, by this time, Heshitai had committed himself to 'ensuring the success of the Embassy' and had sent a misleading report to the emperor on 28 August that the embassy, 'despite not having rehearsed the Kotow, would certainly perform the full ceremonial at the imperial audience' (p. xxxi). ${ }^{26}$

Amherst, obviously unaware of Heshitai's report, wrote in his official report, 'From this time, I am at a loss to account for the proceedings of the Chinese Authorities' (Amherst to Canning, 28 February 1817, in BL IOR G/12/197 (Reel 2) F 270). Heshitai visited Amherst immediately on receipt of his note. Rather than bringing news that the embassy was to be expelled, he told Amherst that the emperor had ordered the embassy to pack up immediately in preparation for leaving for Yuanmingyuan the next day. Amherst checked to make sure that it was understood he would not be performing the kowtow. Guanghui, according to Morrison (1820), seemed to say 'yes' and bowed his head, which the British understood as affirming, 'You are to be received according to the forms you propose' (p. 54). Guanghui, according to Ellis (1817), replied:

Both parties in the discussion had done their duty, but that now the affair was settled, and [the British] might be perfectly easy; the ceremony would not be again mentioned, and that [they] might rely upon the Emperor's kindness, whose heart was truly liberal and expanded. (p. 173)

26 Tuck's (2000) conclusion is puzzling as Heshitai had qualified his expression of support and had made it clear that he could not guarantee the attainment of any of the embassy's objectives. Staunton later wrote that Heshitai's assurances of support were quickly dismissed as unreliable and, after closer scrutiny, were not a sufficient basis on which to comply with the kowtow ceremony (see Minute of Sir George Thomas Staunton, 18 January 1817, in Morse, 1926/1966, vol. 3, pp. 303-304). 
This was a pivotal discussion for the outcome of the embassy for it firmly established in Amherst's mind what was expected of him at any forthcoming imperial reception. He told Canning, 'My invitation to the Tartar Court had been given upon an express understanding that I should not be called upon for the performance of prostration' (Amherst to Canning, 3 March 1817, in BL IOR G/12/197 (Reel 2) F 280).

The British had another surprise. Chang-wei and Yin brought disturbing news that Guanghui and Sulenge were currently being investigated over the conduct of the embassy. The emperor had found them responsible for the expenses incurred by permitting the embassy to leave Tianjin and Guanghui had been stripped of his position in the Salt Department (Ellis, 1817, p. 174). Chang-wei added that further fatal consequences might befall Guanghui if the embassy did not arrive at Peking the following day.

Amherst refused to be hurried. His priority was to make a very dignified entrance at the Chinese capital and he was not prepared to leave Tongzhou until 'every thing connected with the public appearance of the Embassy had been dispatched to Pekin' (Ellis, 1817, p. 174).

So ended a couple of weeks of intense and stressful negotiations for both parties. Not only had Amherst been placed under increasing pressure to comply with Qing tributary diplomatic protocol, but the mandarins faced considerable pressure to ensure that the emperor's instructions were carried out. The negotiations had gone into overdrive at the beginning of the official banquet on 13 August 1816 when Amherst was confronted with a concealed diplomatic 'trip-wire' to establish if he was prepared to perform the kowtow. Amherst, to his credit, had recognised the trap immediately on entering the banquet hall as a result of his pre-departure research on the Golovkin Embassy of 1806, involving a table handsomely dressed in yellow silk with embroidered dragons said to represent the presence of the emperor.

In retrospect, Amherst had been variously pressured and threatened in relation to Staunton, as well as cajoled and induced to kowtow if he wished to secure an audience with the Jiaqing emperor and avoid the immediate expulsion of his embassy. The British had landed some counter-punches of their own by demanding their performance of the kowtow be reciprocated by a mandarin of equivalent rank to Amherst before a portrait of the Prince Regent, which was rejected by the Chinese. The departure of the 
British ships on a reconnaissance mission to Korea and the Ryukyu Islands immediately after landing the party at Dagu had infuriated the emperor and meant that the Chinese Government was responsible for the cost and safety of the embassy's passage overland to Canton.

Admittedly, concessions and allowances had been made by both sides in an effort to keep the embassy on schedule for an audience with the emperor before his departure for Jehol. The dispatch of increasingly more senior mandarins by the Qing court as the embassy advanced closer to Peking indicated the court's determination to achieve a favourable outcome to the impasse over the kowtow. The British became puzzled when, on a number of occasions, it appeared as though they were to be expelled, only to have the order rescinded at the last minute. Thus, the final instruction in late August to proceed from Tongzhou to Peking caught the British by surprise and it was with not a little foreboding that they set off for Yuanmingyuan. 
This text is taken from Britain's Second Embassy to China: Lord Amherst's 'Special Mission' to the Jiaqing Emperor in 1816, by Caroline Stevenson, published 2021 by ANU Press, The Australian National University,

Canberra, Australia.

doi.org/10.22459/BSEC.2020.08 